UNRAM Law Review is licensed under a Creative Commons Attribution 4.0 International License, which permits unrestricted use, distribution, and reproduction in any medium, provided the original work is properly cited. p-ISSN: 2548-9267 | e-ISSN : 2549-2365, Open Access at : http://unramlawreview.unram.ac.id/index.php/ulr

\begin{tabular}{c|c|c|c|c|}
\hline Volume & Issue & Page & October & p-ISSN: 2548-9267 \\
4 & 2 & $174-183$ & 2020 & e-ISSN : 2549-2365
\end{tabular}

\title{
Gender Stereotype in the Formulation of Crime of Rape: A Comparison of Criminal Code and Draft Criminal Code
}

\author{
Abu Sa'it \\ Magister of Law of Faculty Law Mataram University \\ Email: abusait1579@gmail.com \\ Imas Octaviana Dewi \\ Magister of Law of Faculty Law Mataram University \\ Email: imasoctavia00@gmail.com \\ Lalu Panca Tresna \\ Magister of Law of Faculty Law Mataram University \\ Email: lalupancatresna@gmail.com \\ Lalu Rangga Satria Wijaya \\ Magister of Law of Faculty Law Mataram University \\ Email: laluranggasatria@gmail.com \\ Yuni Ristanti \\ Magister of Law of Faculty Law Mataram University \\ Email: yuniristanti4@gmail.com
}

\begin{abstract}
Rape is one of the crimes that may embody stereotype gender, likewise in Indonesian Criminal Code. However there is development conception concerning crimes of rape put forward in The Draft of Criminal Code. This study aims to determine the different provision of crimes of rape in Criminal Code and The Draft Criminal Code. The result of this study concluded that the provision of rape in the Draft Criminal Code have more advance than the provision of rape in Criminal Code. The Draft Criminal Code has renounce crime of rape base on gender by not showing woman as the only victim of rape. Furthermore the provisions of rape in the draft criminal code have asserted method of rape that not only by intercourse. Therefore the provision of crime of rape in the draft criminal code can include rape whose victim are boys or men.
\end{abstract}

Keyword: Rape, Criminal Code, Draft Criminal Code, Stereotype Gender.

\section{INTRODUCTION}

The 1945 Constitution, Article 27, paragraph (1), states that "All citizens have the same position in law and government and are obliged to respect the law and government without exception." In this article, "All citizens of the State" refers to men and women who have the same position in law and government. In the past, there is a general assumption that a man who is well taken care of should be independent, aggressive, and strong. Whereas a 
woman who is well taken care of should not be independent, have a nurturing nature, and not be attracted to strength. At the same time, generally, masculine characteristics are considered healthy and good by society, while feminist characteristics are considered unpleasant. ${ }^{1}$

Stereotyping against women or one particular gender creates a negative impression which is a must for women. This stereotype is a form of gender injustice. For example, there is an assumption that women like to dress up to attract the opposite sex. In the event of rape, it is often concluded that the incident begins with women's attitudes, without analyzing all the facts that cause rape. The problem that still arisen in this century is the assumption that women are the trigger for rape. In addition, women are considered physically and intellectually weak, so they are not worthy of being leaders. Women also considered have a lot of limitations, unlike men. ${ }^{2}$ The stereotypes against women who are considered weak and become normal judgment in society causing gender-based violence, namely violence perpetrated by different sexes due to the normal view that puts one gender superior and the other are considered inferior. ${ }^{3}$

Article 285 of the Criminal Code which regulates the crime of rape states "Whoever by means of violence or threat of violence forces a woman to have intercourse with him outside of marriage, is threatened with committing rape with a maximum imprisonment of twelve years."The word "a woman" in this article affirmed that the victim of this act of rape is only a woman. Whereas in this day and age the victims of rape are not only women. Men can also be victims of rape. The example is the case of May BintiMansyur in 2011 who raped 6 teenagers. ${ }^{4}$

In her case, May forced the victims who were still a minor to have intercourse with her using seduction. May who committed the crime of rape was charged for break the law no. 23 of 2002 concerning Child Protection and was sentenced to 12 years in prison. The rape article in the Criminal Code cannot be applied because its elements are not fulfilled.

After the news broke out, various negative narratives emerged on social media. In Indonesia, the stigma of rape is still reckless. It was as if only women had been victims, and men were the perpetrators.

The consensus has always positioned men as strong, masculine. He shall not be subject to a crime, particularly the crime of rape. This view is causing men who become victims of rape rarely report. They afraid of being considered flabby, unmanly, or even not trusted by law enforcers. Rape can occur by and to anyone. This principle is not well understood by some groups in society.

The case of rape against men indicates a shift in the object of the crime of rape, not only women but men can also become victims. Article 285 of the Criminal Code can not apply in the case of rape whose victim is a man. Considering that the Criminal Code is a legacy product from the Dutch, Indonesia must remodel or even make its criminal code due to the development of today's society is far more advanced than the time the Criminal Code was promulgated.

Since decades ago, Indonesia has made efforts to recode the Criminal Code until now, but it cannot be ratified because there are still articles that need to be improved. The revision of the Criminal Code is still causing debate between pro and contra parties. The criminalization of an act must be in accordance with the values adhered to in Indonesia, namely to whichextentd

\footnotetext{
${ }^{1}$ Fatimah Saguni. (2014). Pemberian Stereotype Gender, 6 (2).

${ }^{2}$ Ni Nyoman Sukerti, I Gst. Ayu Agung Ariani. 2016. Gender dalam Hukum. Bali: Pustaka Ekspresi, p. 6.

${ }^{3}$ Ibid.

${ }^{4}$ https://news.detik.com/berita/d-2621929/dibui-12-tahun-tante-may-garap-korban-pertama-saat-suaminya-tertidur
} 
the act is against or does not contradict the fundamental values prevailing in society, and by the community it is deemed appropriate or improper to be punished in order to carry out the welfare of the community.

The Criminal Code should be an urgent national need to be examined in the context of legal reform that guarantees justice and peace in people's lives. The Criminal Code is no longer relevant to be enforced. The Draft Criminal Code that has contained values of religion, customary and positive law is reflected in the formulation of its articles shall enact as an act immediately for a better life order and peaceful life for the Indonesian people.

Based on the background described above, we are interested to study the crime of rape. The legal issue formulated as follows: What are different regulation of rape based on gender in the National Criminal Code and the Draft National Criminal Code?

\section{METHOD}

This study is normative legal research or doctrinal research. In this study, the authors reviewed the existing regulations in the Criminal Code and the Draft National Criminal Code regarding the crime of rape. The approach used in this study is the conceptual approach and the statute approach. The data collecting by the literature study i.e. searching and review data from books, document in the library

\section{ANALYSIS DAN DISCUSSION}

\section{Stereotype Gender in Crime of Rape}

Gender defines as the differentiation of roles, attributes, attitudes, or behaviors that grow and develop in society or that society deems appropriate for men and women. For example, in a society, the role of men is described as the head of the family, the role of women as housewives. Female characteristics are usually described as feminine, such as gentle, emotional, submissive, etc. Male characteristics are described as masculine, such as strong, assertive, rational, and so on. The reality not always consistent with those characteristic stereotypes. There are some women who are strong, rational, and assertive, likewise, there are men who are graceful, emotional, and obedient. Roles, responsibilities, social relations between women and men, all expectations are learned and socialized from an early age. Because it is obtained from learning methods, from culture or traditions that have been adopted from a downward spiral (culturally learned behavior), this behavior is validated by the community as a local culture (culturally assigned behavior).

Gender stereotypes are labeling of the male or female sex, which always has a negative connotation, causing problems. For example, women are always seen as weak, timid, talkative, emotional, and less responsible, while men are seen as strong, tough, rational, and selfish. ${ }^{5}$ Girls are considered more vulnerable than boys to rape or other sexual abuse by family members, or by those in higher positions, or by strangers. ${ }^{6}$ In many cases, women victims of rape are forced

\footnotetext{
${ }^{5}$ Mufidah. (2009). Pengurusutamaan Gender pada basis keagamaan, Malang: UIN-Malang Press, p.7.

${ }^{6}$ Nursyahbani Katjaasungkana Mumtahanah. (2002). Kasus-Kasus Hukum Kekerasan Terhadap Perempuan (Sebuah Drama Tentang Patriarki dan Dominasi Laki-Laki). Jakarta, p. xxvi.
} 
to marry their rapist. ${ }^{7}$ That action is not the solution. On the contrary, forcing women to marry their rapist is a mistake cause it triggers the traumatic for victims of rape because they are getting closer to the rapist.

Women oftentimes describe as the only victim of rape. Since women stereotype as feminine and weak they cannot be the perpetrator. On the contrary, man who stereotype as strong cannot be the victim of rape. However some study indicates that number of men have been victim of rape. Some study in America and British showed that about 3 to $8 \%$ of American and British men having experienced an adulthood incident of sexual assault in their lifetime. ${ }^{8}$ However these numbers seem fewer than the real number of victim. This is considering a lot of unreported cases of men as victim of rape. Considerable study confirmed this hypothesis. Few male rapes appear in police files or other official records. Very few male rape victims report their assault to police because they think they will experience negative treatment, be disbelieved, or blamed for their assault. ${ }^{9}$

The stereotype of sexual violence also affirmed in situation of armed conflict. Rape and other sexual violence is one of war crimes offence. In armed conflict women and men can be subject of sexual violence. L Stemple wrote this issue by affirm:

"Conventional analyses of gender, armed conflict and peacekeeping habitually emphasise the vulnerabilities of women and girls, and their vulnerabilities to sexual violence in particular. They tend, therefore, to presuppose and reproduce gendered assumptions that pit women as the inevitable victim, while men are represented as a 'monolithic perpetrator class" 10

Sandesh Sivakumaran describes that sexual violence against men take place in nearly every armed conflict in which sexual violence is committed. ${ }^{11}$ Certain number of men victim in sexual violence in the event of armed conflict is hard to confirm. This is due to no report from victim. There are some factors causing men as victim of sexual assault hard to speak up. Those factors are combination of shame, confusion, guilt, fear and stigma. ${ }^{12}$

Man as victim of rape not only happened in international armed conflict, but also in noninternational armed conflict. This crime is a war crime as stipulated in Rome Statute 1998. However the arrangements of protection of victim of non-international armed conflict is not as comprehensive as the arrangements of international armed conflict. To strengthening the protection of armed conflict some scholar propose conception of using human rights law in the situation of armed conflict. ${ }^{13}$ Therefore in the situation of armed conflict, the rules apply for crimes of rape are international humanitarian law and human rights law.

${ }^{8}$ Turchick, Jessica A, and Edwards Katie. (20110. “Myths About Male Rape: A Literature Review”, Psychology of Men and Masculinity, 13(2): 211.

${ }^{9}$ Walker Jayne, Archer Jhon, Lowe Michelle, Effect of Rape on Men: A Descryptive Analysis, (https://www.researchgate. net/publication/7961649 Effects of Rape on Men A Descriptive Analysis, (Accesed March, 2, 2020), p. 4.

${ }^{10}$ L. Stemple. (2009). 'Male rape and human rights'. Hastings Law Journal, 60 (3): 635.

${ }^{11}$ Sivakumaran Sandesh, "Sexual Violence Against Men in Armed Conflict". The European Journal of International Law, $18(2): 255$

12 Ibid.

${ }^{13}$ Zunnuraeni. (2013). "PENERAPAN HUKUM HAK ASASI MANUSIA PADA SITUASI KONFLIK BERSENJA TA“, Jurnal Ilmu Hukum, 4.(1): 102.
} 


\section{The Provision of Rape in the Criminal Code and the Draft Criminal Code}

Rape stipulates in article 285 of the Criminal Code, which reads: "Anyone who by force or threat of violence forces a woman to have intercourse with him outside of marriage, is threatened for committing rape with a maximum imprisonment of twelve years."."14 Base on legal history, crimes of rape have been regulated for a long time. However, until now Indonesia does not have an explicit regulation regarding the definition of intercourse in article 285 of the Criminal Code. Law enforcers only use interpretations of legal experts (doctrines) or the jurisprudence of the Dutch courts which were formulated decades ago.

Base on the traditional view, rape is defined from a male perspective based on male sexuality. In this view, rape is identified with penetration. Although Article 285 of the Criminal Code does not require penetration as an element of action and does not include sexual history as a condition for being convicted, these two things generally have a very strong influence on law enforcement not to or to continue with charges based on Article 285. Erna SofwanSjukrie, who is one of the expert staff of the Ministry of Women's Empowerment and Child Protection, assesses that the definition of the element of intercourse needs to be expanded in Indonesian legislation because the confusion of norms and unclear interpretation of intercourse results in inconsistencies in interpreting the elements of intercourse by law enforcers. ${ }^{15}$

Article 285 of the Criminal Code only mentions "a woman" who was the victim of rape. Therefore crimes of rape only objected to women as the victim. Other forms of rape, namely women rape men, men rape men, and women rape women do not object to article $285 .{ }^{16}$ The understanding that the problem of rape is more influenced by the male paradigm and becomes a stereotype of women as male sexual objects which trigger rape.

Furthermore, Deborah L. Rhode said that the prohibition against violence against women has served to protect men. NursyahbaniKatjsungkana interpreted Deborah L. Rhode's statement that the prohibition of rape was to protect men so that men always had a virgin woman as their wife. This statement is supported by the rule in old societies such as Asyyiria and Babylonia that hard regulations against the rapist depending on the social and sexual status of the victim. The rape of a girl is considered worst compared to rape committed against a married woman. Ironically, the rapist was not sanctioned, but the victim was indicated to marry the perpetrator. ${ }^{17}$

From a feminist perspective, Article 285 of the Criminal Code contains discrimination against women in the form of labeling. Rape faced by women is an example of the vulnerability of women's position to men's sexual interests. Article 285 of The Criminal Code, although it is not stated directly, that women at the same time considered victims as well as the source of crime, and some people consider this to be normal. This has far-reaching implications for women's lives. They must face violence, coercion, physical, sexual, and psychological abuse. The weak position of women is a consequence of differences in human sexuality.

Article 6 paragraph (1) of Law Number 12 Year 2011 concerning the Formation of Laws and Regulations expressly stated that the material contents of statutory regulations include: a. protection; b. humanity; c. nationality; d. kinship; e. archipelago; f. unity in diversity; g. justice;

\footnotetext{
${ }^{14}$ Kitab Undang-Undang Hukum Pidana. (2014). Klaten: PT.Hamfira

${ }^{15}$ Anugrah Rizki Akbari, dkk. (2016). Reformasi Pengaturan Tindak Pidana Perkosaan, Masyarakat Pemantau Peradilan Indonesia dan Badan Penerbit Fakultas Hukum Universitas Indonesia atas dukungan Australia Indonesia Partnership for Justice: Jakarta.

${ }^{16} \mathrm{Ibid}, \mathrm{p} .30$

${ }^{17}$ Ibid.
} 
h.equality before the law and government; i. order and legal certainty; and/or j. balance and harmony. Point (g) states that the principle of justice meant that every material contained in the laws and regulations must reflect justice proportionately for every citizen without exception. Then Point (h) which states that the principle of equality before the law and government meant that each material content of legislation cannot contain things that are discriminatory based on background, including ethnicity, religion, race, social status, and even gender. However, the regulation of the criminal act of rape in article 285 contains discrimination based on gender. Rape that actually may attack anyone regardless of their gender limited that women as the only victim of rape. It excluded men who may also victims of rape.

Gender discrimination creates vulnerability for women and has the potential to cause violence against women. Discrimination against women indicates that the fulfillment of women's human rights is still neglected. Discriminatory and/or gender-biased laws and regulations also impact on forms of discriminatory treatment. On the other hand, the practice of discrimination occurs as a result of the perception of society that is not responsive to the problems and aspirations of men and women which basically different. Therefore it is important to formulate provisions in the laws and regulations that have gender-responsive characteristics, likewise in technical operational policies. That effort should be made continuously to uphold the respect, protection, and fulfillment of women's human rights. ${ }^{18}$

There have been several attempts to improve the Criminal Code by making the Draft Criminal Code, starting with the recommendation of the 1963 National Law Seminar which called for the draft of the national criminal law codification to be completed immediately. The future national Criminal Code must adapt to new developments, particularly to international developments that have been agreed upon by civilized society.

Rape is regulated in Article 479 of the Draft Criminal Code, which reads:

1) Anyone who by Violence or Threats of Violence forces someone to have intercourse with him, shall be punished for committing rape, with a maximum imprisonment of 12 (twelve) years.

2) Including the crime of rape and the punishment as referred to in paragraph (1) includes actions: a. intercourse with someone with his consent, because that person believes that the person is the legal husband/wife; b. intercourse with children; or c. intercourse with someone, even though it is known that the other person is unconscious or helpless.

3 ) It is also considered to have committed the crime of rape, if in the circumstances as referred to in paragraph (1) and paragraph (2) the obscene act is committed in the form of, a. inserting the genitals into another person's anus or mouth; $b$. inserting another person's genitals into his anus or mouth, or c. inserting a part of his body that is not the genitals or an object into the genitals or anus of another person.

4) In the event that the victim as referred to in paragraph (1) and paragraph (3) is a child, shall be sentenced to imprisonment for a maximum of 15 (fifteen) years.

5) In the event that the victim as referred to in paragraph (1) is a child and is forced to have intercourse with another person, the punishment shall be maximum imprisonment of 15 (fifteen) years.

\footnotetext{
${ }^{18}$ Departemen Hukum Dan Hak Asasi Manusia. (2012). Parameter Kesetaraan Gender dalam Pembentukan Peraturan Perundnag-Undangan, Cet. 2. Jakarta: Kementerian Hukum Dan Hak Asasi Manusia Republik Indonesia.
} 
6) If one of the criminal acts as referred to in paragraph (1) to paragraph (3) results in serious injury, the punishment shall be maximum imprisonment of 15 (fifteen) years.

7) If one of the criminal acts as referred to in paragraph (1) to paragraph (3) results in the death of a person, the punishment shall be added by $1 / 3$ (one third) of the criminal threat as referred to in paragraph (6).

8) If the Victim as referred to in paragraph (4) is a biological child, stepchildren, or child under his guardianship, the punishment shall be added by $1 / 3$ (one third) of the punishment as referred to in paragraph (4).

The article regarding the crime of rape in the Draft Criminal Code has eliminated the word "a woman" who becomes a victim, change it to the word "someone", with the condition that there has been violence or the threat of violence to forces someone to have intercourse. This new rule can eliminate society's stigma against women as a source of crime (victim) and being identified as rape victims due to feminine appearance. The formulation of this article eliminates gender stereotypes and establish a gender-equitable stigma.

The expansion of the formulation of the offense of rape, namely the act of not only having intercourse (inserting the genitals into the vagina) but also inserting the genitals into the anus or mouth or inserting an object (not part of a man's body) into the vagina or inserting a man's penis into the woman's mouth. The act is conducted not only by violence/threats of violence but also by any means against the will or consent of the victim. While the object of the crime is not only adult women who are aware but also helpless fainted women, and underage girls, not only against women who disagree (against their will) but also against women who give their consent because they are under threat, because of an error/ deception or because being a child.

Compared with the formulation of the elements of rape in the Criminal Code, the formulation of the elements of the offense of rape in the Draft Criminal Code is far more adequate. The main thing that is most important to note that is related to the element of rape is the element "against the will" or "without the consent" of the victim. The important elements in the article are: against the will or without the consent of the woman. Why this element is such an important element?.The formulation of rape in the Criminal Code and will fundamentally change the element of rape that has been accepted in court practices for rape cases.

The asserting of this new element will be more helpful in proving the crime of rape because this element makes it easier to fulfill the element of rape than the elements in the Criminal Code. The definition of contravenes the will must be interpreted more extensively, namely: the definition includes anything which is essentially contrary to the will of the victim, including unwanted acts (no consent) of the victim.

Therefore contravenesthe will can be interpreted by suppressing the will of another person that is against the will of the other person so that the other person accepts the will of the person who suppresses or is the same as his own will. For example, using deception, misdirection, especially if the act is committed through coercion, violence, or threats of violence aimed both at the victim and at other people (3rd party) to subdue the victim.

In the Criminal Code and Draft Criminal Code, the crime of rape is placed in the offense of decency. In general, it is stated that an offense of decency is an offense related to (problems) of decency (ethics). This statement shows that determining the limits and definition of decency is 
not simple. Because of that, the boundaries of decency (ethics) depend on the values that live in a society. ${ }^{19}$

This was also admitted by Soesilo who stated that "the destructive nature of the morality of these acts is sometimes very dependent on public opinion at that time and place".${ }^{20}$ Nevertheless, Soesilo formulated examples of actions that can be categorized as offenses of decency ${ }^{21}$ "here in the sense of the word decency, a feeling of shame related to sexual lust, such as intercourse, touching women's breasts, touching a woman's or men's genitals, kissing and so on.

\section{The Case of May Binti Mansur : First Case of Woman as perpetrator of Rape in Indone- sian Court}

Case of men or boys as victim of rape and woman as the perpetrator is the case of May Binti Mansur. This case is the first case in Indonesia court that convicted woman as the perpetrator of crimes of rape, and men or boys as the victim.

The convicted is Emayartinials May Binti (Alm) Mansyur. She persuade and deceive six boys to have intercourse with her. She deliberately does acts that enhancing those boys sexual desire. There were six boys who become the victim of May binti Mansur. They aged 12 years old, 13 years old, 14 years old and 17 years old.

May bintiMansyur case put on trial in Bengkulu District Court. The prosecutor indicted that May Binti(Alm) Mansyur proven guilty by havingintercourse with children as stipulated in Article 81 paragraph (2) of Law Number 23 Year 2002 Concerning The Protection of Children Jo Article 65 paragraph (1) Criminal Code. May Binti Mansur indicted punishment for 12 (twelve) years in prison, pay fine of Rp 60.0000.000 (Sixty Billions Rupiah), subsidiary six years confinement.

Bengkulu District Court verdict : (1) States that Emayartinials May Binti (Alm) Mansur proven legally and convincingly guilty commiting a criminal act of persuading children to have sexual intercourse with her; (2) Sentenced Emayartinials May Binti (Alm) Mansur to eight years in prison and a fine of Rp 60.000.000 (Sixty Billions Rupiah), provided that if not paid 3 months confinement. This verdict stated In "Putusan Pengadilan Bengkulu Nomor: 290/Pid.B/2013/PN.BKL tanggal 03 Desember 2013. The verdict of Bengkulu District Court strengthened in Bengkulu High Court Verdict Number 02/PID.2014/PT.BKL.

The case of May Binti Mansur judged by the court using Article 81 paragraph (2) of Law Number 23 Year 2002 Concerning The Protection of Children. This article regulates obscene acts against children commited with violence or threat of violence, trickery, lies or persuasion. In this case, Article 285 Criminal Code cannot apply due to this article limited women as the only victim of rape. This case proving that the article concerning crimes of rape in the criminal code cannot ensnare all forms of crime of rape.

\footnotetext{
${ }^{19}$ Barda Nawawi Arief. (1996). Bunga Rampai Kebijakan Hukum Pidana. Bandung.

${ }^{20}$ R. Soesilo. (1996). KUHP Serta Komentar-Komentarnya Lengkap Pasal Demi Pasal. Bogor.

21 Beberapa referensi hukum tidak menggunakan istilah "Kesusilaan" melainkanmenggantinyadengan "Kesopanan", salah satu contoh referensi hukum yang menggunakan kata "Kesopanan" adalah KUHP Serta Komentar-Komentarnya Lengkap Pasal Demi Pasal” yang ditulis oleh R. Soesilo.
} 


\section{CONCLUSION}

The regulation regarding the crime of rape in the Criminal Code embody the existence of gender stereotypes, namely women as a weak gender always become victims and men as a strong gender always become perpetrators. This can be seen from the word "a woman" in the formulation of the article on rape in the Criminal Code. The identification of certain gender as victims and as perpetrators in the Criminal Code causing the Criminal Code cannot applied to prosecute the crime of rape where the gender of the perpetrator and victim is not as identified. The case of May Binti (late) Mansur is evidence of the weakness of the rape article in the Criminal Code. Meanwhile, the rape regulation in the draft Criminal Code no longer shows gender stereotypes. The Draft Criminal Code expands the formulation of the crime of rape, in which the perpetrator and victim are not identified based on gender and the method of rape is not only by having sexual intercourse.

\section{Bibliography}

Books:

Anugrah Rizki Akbari, dkk (2016), Reformasi Pengaturan Tindak Pidana Perkosaan, Masyarakat Pemantau Peradilan Indonesia dan Badan Penerbit Fakultas Hukum Universitas Indonesia atas Dukungan Australia Indonesia Partnership for Justice. Jakarta.

Barda Nawawi Arief. (1996). Bunga Rampai Kebijakan Hukum Pidana. Bandung.

Kitab Undang-Undang Hukum Pidana. (2014). Klaten: PT.Hamfira

Mufidah. (2009). Pengurusutamaan Gender Pada Basis Keagamaan. Malang: UIN-Malang Press.

Ni Nyoman Sukerti, I Gst. Ayu Agung Ariani. (2016). Gender Dalam Hukum. Bali: Pustaka Ekspresi.

Nursyahbani Katjaasungkana Mumtahanah. (2002). Kasus-Kasus Hukum Kekerasan Terhadap Perempuan (Sebuah Drama Tentang Patriarki dan Dominasi Laki-Laki). Jakarta

R. Soesilo. (1996). KUHP, Serta Komentar-Komentarnya Lengkap Pasal Demi Pasal. Bogor. Departemen Hukum Dan Hak Asasi Manusia. (2012). Parameter Kesetaraan Gender dalam Pembentukan Peraturan Perundnag-Undangan, Cet. 2. Jakarta: Kementerian Hukum Dan Hak Asasi Manusia Republik Indonesia

Journal:

Fatimah Saguni. (2014). "Pemberian Stereotype Gender". 6 (2).

L. Stemple. (2009). “Male Rape And Human Rights”. Hastings Law Journal, 60 (3): 635.

Sivakumaran Sandesh, "Sexual Violence Against Men in Armed Conflict", The European Journal of International Law. 8 (2): 255

Turchick, Jessica A, and Edwards Katie. (20110. "Myths About Male Rape: A Literature 
Review". Psychology of Men and Masculinity, 13(2): 211

Zunnuraeni, 2013, "PENERAPAN HUKUM HAK ASASI MANUSIA PADA SITUASI KONFLIK BERSENJATA“. Jurnal Ilmu Hukum, 4.(1): 102.

World Wide Web:

https://news.detik.com/berita/d-2621929/dibui-12-tahun-tante-may-garap-korban-pertamasaat-suaminya-tertidur

Walker Jayne, Archer Jhon, Lowe Michelle, Effect of Rape on Men: A Descryptive Analysis, (https://www.researchgate.net/publication/7961649 Effects_of_Rape_on_Men_A Descriptive Analysis, (Accesed March, 02, 2020). 